\title{
Case for diagnosis
}

\author{
Caso para diagnóstico
}

\section{Carolina Ribas do Nascimento ${ }^{1}$ Milton Cury Filho ${ }^{3}$}

\section{CASE REPORT}

Female patient, white, 37 years old, reported a nodule on the dorsum of the proximal phalanx of the left fourth finger after trauma at age 12. The lesion had grown slowly bigger over the previous two years. Diabetic patient with adequate glycemic control. Examination revealed a nodule of about four inches in diameter on the dorsum of the proximal phalanx of the left fourth finger, of a soft consistency, not adhering to deep plane and painless to the touch (Figure 1). Patient complained of mild limitation of movement in the affected finger since the lesion had increased in size. After initial diagnostic hypotheses, we carried out fine needle aspiration which confirmed our suspicions. In view of the patient's complaints about limitation of movement and the fact that the lesion was unsightly, it was decided, together with the patient, to perform surgery to remove the tumor (Figure 2). Pathology exam confirmed the diagnosis (Figure 3).

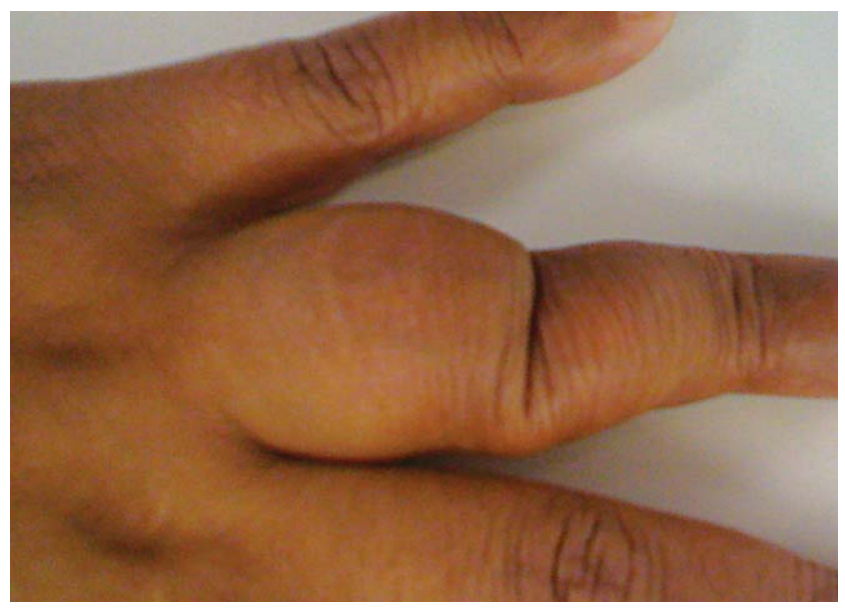

Figure 1: Nodule on the dorsum of the proximal phalanx of the left fourth finger. Approximately $3 \mathrm{~cm}$ in diameter, with soft consistency, not adhering to deep planes

Received on 18.01.2011.

Approved by the Advisory Board and accepted for publication on 24.03.2011.

* Work done at the Instituto Lauro de Souza Lima (ILSL), Bauru (SP), Brazil.

Conflict of interest: None

Financial funding: None

(

Master in Dermatology, Preceptor of Dermatology at the Instituto Lauro de Souza Lima (ILSL), Bauru (SP), Brazil.

Orthopedic physician at the Instituto Lauro de Souza Lima (ILSL), Bauru (SP), Brazil.

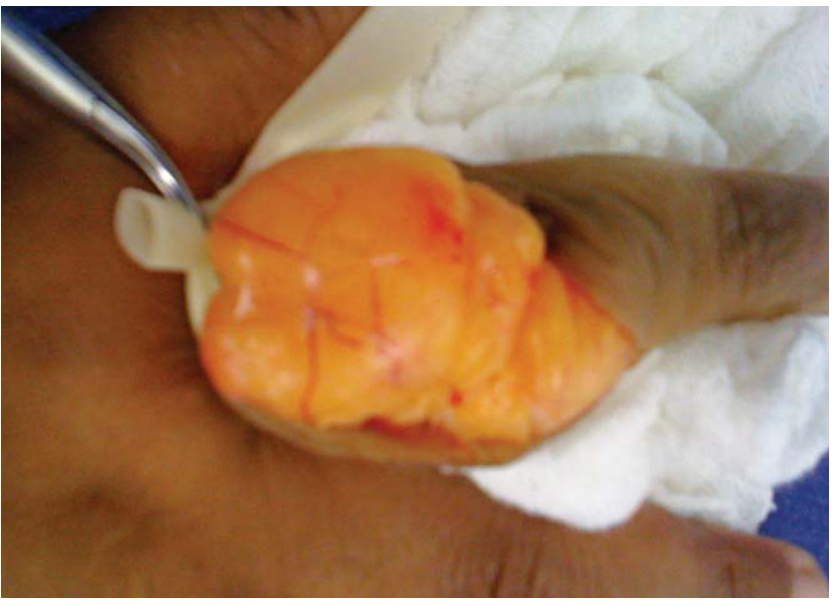

FIGURE 2: Resection of the lesion

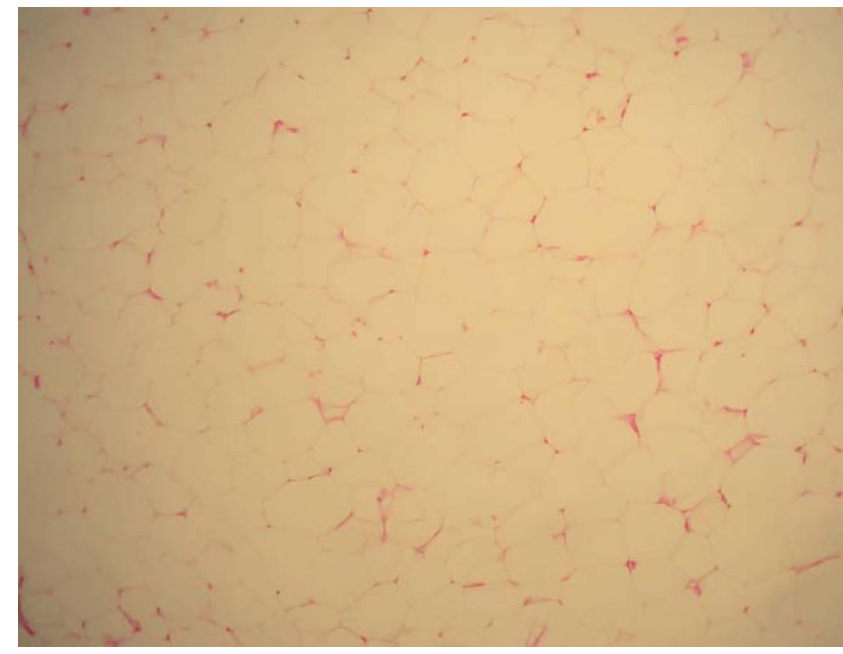

FIGURE 3: The histological findings (haematoxylin-eosin, original magnification $\mathrm{X}$ ?) confirmed of clinical suspition

(C)2012 by Anais Brasileiros de Dermatologia 


\section{DISCUSSION}

Lipomas are common benign mesenchymal neoplasms, ${ }^{1}$ composed of mature fat cells that may or may not be surrounded by a conjunctive tissue capsule. ${ }^{1,2,3}$ Palpable lesions are formed of a firm, elastic consistency causing raised areas of skin. Their size can vary from half to several inches in diameter. The skin covering the lipomas is usually of normal appearance. The tumors normally occur in isolation, but may be multiple. Common sites include the neck and trunk. ${ }^{2}$ They can frequently be found in the adult population, particularly in obese patients, and are sometimes linked to trauma. They rarely occur on the hand, and lipomas involving the fingers are extremely rare. $1,2,4,5$

The first patient with a lipoma on the finger was reported by Stein in 1959. ${ }^{2}$ The incidence of such lesions in this location is $1 \%$. Four Fewer than 20 cases have been reported in the literature we consulted. Although lipomas are rare in the fingers, they should be considered in the differential diagnosis of benign soft tissue masses at that particular location.

\begin{abstract}
Lipomas are common benign mesenchymal tumors composed of mature fat cells that may or may not be surrounded by a thin, fibrous capsule. The link with trauma has already been described. Lipomas involving the fingers are extremely rare but must be considered in the differential diagnosis of benign soft tissue masses in this particular location.
\end{abstract}

Keywords: Finger phalanges; Lipoma; Neoplasms

Resumo: Lipomas são neoplasias mesenquimais benignas comuns constituídas de células gordurosas maduras que podem ou não estar envoltas por cápsula conjuntiva. A relação com o trauma já foi descrita. Aqueles envolvendo os dedos são extremamente raros, mas devem ser considerados no diagnóstico diferencial das massas benignas de tecidos moles em tal localização.

Palavras-chave: Falanges dos dedos da mão; Lipoma; Neoplasias

\section{REFERENCES}

1. Stuffer M, Thurner JE. Lipoma of the index digit - a very rare location. Arch Orthop Trauma Surg. 1995;114:239-40.

2. Ersozlu S, Ozgur AF, Tandogan RN. Lipoma of the index finger. Dermatol Surg. 2007;33:382-4.

3. Rosa IP, Garcia MLP, Greco JC, Tovo Filho R. Lipomas - Classificação e técnica cirúrgica. An Bras Dermatol. 1988;63:369-70.

4. Schofft H, Hager D, Dunst KM, Huemer GM. Giant lipoma of the thenar. Wien Klin Wochenschr. 2007;119:149.

5. Azuma R, Demitsu T, Hiratsuka Y, Kakurai M, Imagawa I, Yoneda K, et al. Subcutaneous lipoma on the index digit presenting as fingertip bulging. $J$ Dermatol. 2006;33:386-7.

\author{
MAILING ADDRESS: \\ Carolina Ribas do Nascimento \\ Rodovia Comandante João Ribeiro de Barros, KM \\ 225-226, \\ Bauru. 17034-971 São Paulo, SP - Brazil \\ E-mail:dra.carolribas@gmail.com
}

How to cite this article: Nascimento CR, Barreto JA, Cury Filho M. Case for diagnosis - Lipoma on the dorsum of the finger: a rare location. An Bras Dermatol. 2012;87(2):317-8. 